\title{
The Effect of Gamma-Irradiated Nitrate-Reducing Bacteria in Decreasing the In Vitro Production of Methane by Buffalo Rumen Liquid
}

\author{
R. Rahmani ${ }^{1}$, M.R. Pikoli ${ }^{1}$ and I. Sugoro ${ }^{2}$ \\ ${ }^{I}$ Department of Biology, Faculty of Science and Technology, Syarif Hidayatullah State Islamic University Jakarta, \\ Jl. Ir. H. Juanda No. 95, Ciputat, Tangerang Selatan 15412, Indonesia \\ ${ }^{2}$ Center for Isotopes and Radiation Application, National Nuclear Energy Agency, \\ Jl. Lebak Bulus Raya No. 49, Jakarta 12070, Indonesia
}

\section{ARTICLE INFO}

Article history:

Received 26 February 2017

Received in revised form 11 July 2019

Accepted 24 September 2019

Keywords:

Nitrate reducing bacteria

Inactive

Gamma iradiation

Rumen

Methane

\begin{abstract}
A B S T R A C T
Ruminant livestock undeniably contributes to the increase of greenhouse gases by emitting methane. One strategy used to reduce methane emission is by applying nitrate-reducing bacteria (NRB). Utilizing active NRB has a side effect of acidosis in rumen liquid in an uncontrolled condition. Alternatively, NRB can be applied in an inactive form. The aim of this study was to examine the use of gamma irradiation on NRB to be used for decreasing methane production by buffalo rumen liquid. The examination was performed in vitro and involved comparison to other treatments, which were active NRB, autoclaved NRB, and without NRB. The result showed that the NRB in either active or the inactive condition affected fermentation of the rumen microorganisms. There were differences in $\mathrm{pH}$ values, digestibility of organic matters, ammonia, total and partial volatile fatty acids, and methane production between all treatments after 24 and $48 \mathrm{~h}$ of incubation. All treatments showed significant differences for each parameter, except for the gas production $(\mathrm{p} \leq 0.05)$. The irradiated NRB produced slightly more methane, i.e. 3.0 and $10.4 \mathrm{ml} / 200 \mathrm{mg}$ after 24 and $48 \mathrm{~h}$ incubation, respectively, compared to the active $\mathrm{NRB}$, autoclaved NRB, and no-NRB-addition treatments, i.e., 2.0 and 8.0; 7.8 and $11.7 ; 8.0$ and $12.4 \mathrm{ml} / 200 \mathrm{mg}$, respectively. In conclusion, the irradiated NRB has a potency as a supplement feed for buffaloes to reduce methane production without the risk of acidosis in the rumen liquid.
\end{abstract}

(C) 2019 Atom Indonesia. All rights reserved

\section{INTRODUCTION}

The global warming takes place today due to the increasing amount of gas emissions into the atmosphere. Methane $\left(\mathrm{CH}_{4}\right)$ is one of the three primary greenhouse gasses responsible for the temperature elevation that are three times more harmful than the other gasses, i.e., carbon dioxide $\left(\mathrm{CO}_{2}\right)$ and nitrous oxide $\left(\mathrm{N}_{2} \mathrm{O}\right)$ [1]. The amount of atmospheric $\mathrm{CH}_{4}$ has increased 2.5-fold for over the past three centuries [2].

The ruminant livestock sector generates more greenhouse gas for it contributes $26 \%$ of the total methane emission [3]. Most (80-95\%) of the $\mathrm{CH}_{4}$ is emitted from the process of methanogenesis in the

\footnotetext{
*Corresponding author.

E-mail address: irawans@batan.go.id

DOI: https://doi.org/10.17146/aij.2019.1006
}

rumen of the digestive system, and the remaining $5-20 \%$ is from the large intestine. The gas is released into the atmosphere as the animal breathes [4]. The release of methane causes a loss of more than $15 \%$ of the total energy ingested. Therefore, minimizing $\mathrm{CH}_{4}$ production increases the efficiency of livestock production, while reducing greenhouse gasses creates a better environment [5].

Various strategies in decreasing the enteric $\mathrm{CH}_{4}$ emission from ruminants have been proposed or under investigation. One approach related to the modification of ruminant feed and microorganisms is by using nitrate-reducing bacteria (NRB). Some studies showed that the NRB cna compete with methanogenic bacteria for utilizing hydrogen [6-8]. The addition of active culture of NRB resulted in methane reduction without decreasing the in vitro true digestibility (IVTD), as compared to the 
treatments containing nitrate with autoclaved microbial cultures or without any culture. It is revealed that to reduce methane emission, the NRB can be used as probiotic to prevent the accumulation of nitrites when sodium nitrate is used [9].

The NRB in inactive condition has been used to decrease the accumulation of nitrites to the level that is not toxic to the host [10]. Inactivation by using hot steam from an autoclave makes the NRB not grow, and several enzymes inactive, but they can still reduce methane production. This method still has a weakness; therefore, it is necessary to conduct further research using alternative methods, for instance, inactivation of bacteria with gamma $(\gamma)$ irradiation. This method inactivates cell growth, but metabolic activities can still run [11]. Preliminary research showed that NRB can be inactivated by $\gamma$-irradiation with dose of $1500 \mathrm{~Gy}$.

Therefore, the current study aimed to examine the use of the NRB isolated from the buffalo rumen, in both active and inactive conditions (either by irradiation and autoclaving), to reduce the methane emission.

\section{EXPERIMENTAL METHODS}

\section{Inactivation of NRB}

This study used isolate KS1 as nitratereducing bacteria. First, isolate KS1 was inoculated into a modified medium of NRB agar $\left(0.5 \mathrm{~g} \mathrm{KNO}_{3}\right.$, $0.1 \mathrm{ml}$ microminerals, $5 \mathrm{ml}$ macrominerals, $3 \mathrm{~g}$ yeast extract, and $2 \mathrm{~g}$ agar, with a $\mathrm{pH}$ of 6.8) [12] and incubated at $39{ }^{\circ} \mathrm{C}$ for $48 \mathrm{~h}$ in an anaerobic jar. For multiplicating the cell culture, the growing cells were inoculated into $30 \mathrm{ml}$ NRB broth (without agar) and incubated at $39{ }^{\circ} \mathrm{C}, 120 \mathrm{rpm}$, for $48 \mathrm{~h}$ in anaerobic condition with the addition of $\mathrm{CO}_{2}$. Total cell concentration was determined by the dilution method. Before inactivating, the isolate was examined for Gram reaction, cell morphology, nitrate reducing ability, and purity [13]. Then, the verified NRB culture with a total concentration of $10^{6}$ cells $/ \mathrm{ml}$ was inactivated, either by gamma irradiation at a dose of $1.5 \mathrm{kGy}$ with a dose rate of $20 \mathrm{kGy} / \mathrm{h}$, or by autoclaving at $121{ }^{\circ} \mathrm{C}$ for 15 minutes.

\section{Determination of in vitro gas production}

The syringes containing the substrate were prepared with four treatments, designated as A, B, $\mathrm{C}$, and $\mathrm{D}$, as follows: $\mathrm{A}$ is the culture with active or live NRB; B with irradiated NRB; $C$ with autoclaved
$\mathrm{NRB}$; and D without NRB. A total of $3 \mathrm{ml}$ culture, according to the treatments, was added to each of the prepared syringes and incubated at $39{ }^{\circ} \mathrm{C}$ for 24 and $48 \mathrm{~h}$. The parameters measured were: $\mathrm{pH}$; ammonia production; total volatile fatty acids (VFA); acetic, propionic, and butyric acid as partial VFA; microbial protein synthesis by radioisotope of ${ }^{32} \mathrm{P}$ [14]; digestibility of organic matters (DOM); gas production and methane production. The $\mathrm{pH}$ was measured by a $\mathrm{pH}$ meter; ammonia production was determined by Conway microdiffusion technique; total and partial VFA concentrations were examined by gas chromatography method; digestibility of organic matters was measured by gravimetric method; and concentration of gases was examined by an MRU Gas Analyzer®. Each treatment was performed in triplicates.

\section{Statistical analysis}

The data was analyzed by using one-way analysis of variance which was performed by SPSS Statistics version 20.0 (IBM Inc.). The means comparison by Duncan's Test were applied with the significance level of 0.05 .

\section{RESULTS AND DISCUSSION}

The results obtained showed that the NRB, both in active and inactive conditions, affected fermentation by rumen microorganisms. There were differences in $\mathrm{pH}$ values, digestibility of organic matters (DOM), ammonia production, total VFA, partial VFA, and $\mathrm{CH}_{4}$ production under all treatments after 24 and $48 \mathrm{~h}$ of incubation (Table 1). All the treatments showed significant differences for each parameter, except for gas production ( $\mathrm{p} \leq 0.05$ ).

Another study reported, differently, that the addition of NRB leads to the increase of $\mathrm{pH}$ in rumen liquid [9] The $\mathrm{pH}$ of the cultures in our study tended to decline until $24 \mathrm{~h}$ and slightly increased until $48 \mathrm{~h}$ of incubation. NRB need more time to adapt in the rumen liquid before they carry out normal activities. Another study showed that the addition of NRB leads to the neutral $\mathrm{pH}$, i.e., 7 [6]. $\mathrm{pH}$ is one of the factors that support the success of the fermentation process because it influences the growth and enzymatic activity of microorganisms that play a role in the fermentation process [15]. Therefore, the $\mathrm{pH}$ in the four treatments did not cause any significant problems since they were all in the optimal range of $\mathrm{pH}$ for rumen microbial activities, i.e., 6.5-7. 
Table 1. Measurement results of the parameters under the four treatments

\begin{tabular}{|c|c|c|c|c|c|}
\hline \multirow{2}{*}{ Parameter } & \multirow{2}{*}{ Time (h) } & \multicolumn{4}{|c|}{ Treatments } \\
\hline & & $\mathrm{A}$ & $\mathrm{B}$ & $\mathrm{C}$ & $\mathrm{D}$ \\
\hline \multirow{3}{*}{$\mathrm{pH}$} & 0 & $7.2^{\mathrm{a}}$ & $7.2^{\mathrm{a}}$ & $7.2^{\mathrm{a}}$ & $7.2^{\mathrm{a}}$ \\
\hline & 24 & $6.9^{\mathrm{a}}$ & $6.9^{\mathrm{a}}$ & $7.0^{\mathrm{a}}$ & $6.9^{\mathrm{a}}$ \\
\hline & 48 & $6.6^{\mathrm{a}}$ & $7.0^{\mathrm{c}}$ & $6.9^{\mathrm{b}}$ & $6.9^{\mathrm{bc}}$ \\
\hline \multirow{3}{*}{ Amonia (mM) } & 0 & $2.4^{\mathrm{a}}$ & $2.4^{\mathrm{a}}$ & $2.4^{\mathrm{a}}$ & $2.4^{\mathrm{a}}$ \\
\hline & 24 & $2.7^{\mathrm{b}}$ & $2.6^{\mathrm{b}}$ & $2.4^{\mathrm{a}}$ & $2.3^{\mathrm{a}}$ \\
\hline & 48 & $2.8^{\mathrm{c}}$ & $2.6^{\mathrm{a}}$ & $2.5^{\mathrm{b}}$ & $2.5^{\mathrm{bc}}$ \\
\hline \multirow{3}{*}{$\begin{array}{l}\text { VFA total } \\
(\mathrm{mmol} / 100 \mathrm{ml})\end{array}$} & 0 & $108.1^{\mathrm{a}}$ & $107.0^{\mathrm{a}}$ & $106.0^{\mathrm{a}}$ & $105.7^{\mathrm{a}}$ \\
\hline & 24 & $88.9^{\mathrm{a}}$ & $92.0^{\mathrm{a}}$ & $92.3^{\mathrm{a}}$ & $115.0^{\mathrm{b}}$ \\
\hline & 48 & $90.2^{\mathrm{a}}$ & $91.7^{\mathrm{a}}$ & $88.1^{\mathrm{a}}$ & $118.3^{\mathrm{b}}$ \\
\hline \multirow{3}{*}{$\begin{array}{c}\text { Acetic } \\
(\mathrm{mmol} / 100 \mathrm{ml})\end{array}$} & 0 & 69.5 & 68.9 & 69.1 & 70.0 \\
\hline & 24 & 45.9 & 48.5 & 51.0 & 72.0 \\
\hline & 48 & 46.8 & 49.3 & 48.4 & 74.6 \\
\hline \multirow{3}{*}{$\begin{array}{c}\text { Propionic } \\
(\mathrm{mmol} / 100 \mathrm{ml})\end{array}$} & 0 & 35.0 & 34.5 & 33.5 & 37.0 \\
\hline & 24 & 39.2 & 40.0 & 38.2 & 38.5 \\
\hline & 48 & 39.6 & 39.3 & 36.5 & 39.1 \\
\hline \multirow{3}{*}{$\begin{array}{c}\text { Butiric } \\
(\mathrm{mmol} / 100 \mathrm{ml})\end{array}$} & 0 & 3.6 & 3.6 & 3.5 & 3.7 \\
\hline & 24 & 3.8 & 3.4 & 3.0 & 4.6 \\
\hline & 48 & 3.9 & 3.1 & 3.0 & 4.6 \\
\hline \multirow{3}{*}{$\begin{array}{l}\text { Ratio Acetic : } \\
\text { Propionic }\end{array}$} & 0 & 2.0 & 2.0 & 2.1 & 1.9 \\
\hline & 24 & 1.2 & 1.2 & 1.3 & 1.9 \\
\hline & 48 & 1.2 & 1.3 & 1.3 & 1.9 \\
\hline \multirow{2}{*}{$\operatorname{DOM}(\%)$} & 24 & $30.0^{\mathrm{b}}$ & $27.5^{\mathrm{c}}$ & $32.8^{\mathrm{a}}$ & $26.9^{c}$ \\
\hline & 48 & $57.8^{\mathrm{a}}$ & $57.2^{\mathrm{a}}$ & $56.1^{\mathrm{a}}$ & $53.4^{\mathrm{b}}$ \\
\hline \multirow{3}{*}{$\begin{array}{c}\text { Ratio Protozoa } \\
\text { Bacteria }\end{array}$} & 0 & $2.0^{\mathrm{a}}$ & $2.0^{\mathrm{a}}$ & $2.0^{\mathrm{a}}$ & $2.0^{\mathrm{a}}$ \\
\hline & 24 & $0.7^{\mathrm{c}}$ & $1.3^{\mathrm{b}}$ & $1.3^{\mathrm{b}}$ & $1.8^{\mathrm{a}}$ \\
\hline & 48 & $0.8^{\mathrm{a}}$ & $0.9^{\mathrm{a}}$ & $0.6^{\mathrm{a}}$ & $0.8^{\mathrm{a}}$ \\
\hline
\end{tabular}

A: active NRB; B: $\gamma$-irradiated NRB; C: autoclaved NRB; D: without NRB; DOM: Digestibility of Organic Matters. Different superscript letter $\left({ }^{\text {abcd }}\right)$ through a column shows a significant difference $(\mathrm{p}<0.05)$.

The changes in $\mathrm{pH}$ value were influenced by the content of ammonia and VFA produced by the rumen microorganisms. Ammonia resulted from the reduction of nitrate by NRB and was derived from protein degradation [16]. The content of ammonia caused the $\mathrm{pH}$ to be more alkaline. The content of ammonia in the treatment with either active or inactive NRB was higher than that without the addition of NRB. These results confirmed that the inactivated NRB have metabolic ability. On the contrary, the VFA values, both from the active or inactive NRB, were lower than those without the addition of NRB. It was assumed that the NRB stimulated the increasing of rumen microbial growth. The VFA values decreased since they were assimilated into monomers in synthesizing carbohydrate, lipid, and protein for the growth of rumen microorganisms [17].

The composition of the partial VFA affected methane production by rumen microorganisms, especially the group of methanogens. Acetic acid was the highest content of partial VFA resulting from all of the treatments. There was an intermediate compound produced by types of acetonotrophic bacteria before the formation of methane [18]. The presence of propionic and butyric acids indicated the inhibition of acetate production, which resulted in lower production of methane. Reduction of methane can be detected from the decrease in acetate and propionate ratio [18]. In this study, the acetate and propionate ratio decreased in all treatments. The ratio after $48 \mathrm{~h}$ of incubation in the order from the lowest to the highest was the treatment of active (1.18), irradiated (1.25), autoclaved (1.33), and without NRB (1.91). The NRB obtained their final electron acceptor as hydrogen from acetic acid, then transferred them to the denitrification process that requires hydrogen to make some ammonia [20].

The results from the measurement of DOM supported the detection of ammonia and VFA. The DOM value showed polysaccharides, lipids, and proteins contained in forage sorghum substrate degraded by microorganisms in the rumen liquid. The addition of both active and inactive NRB lead the DOM value higher than those without the addition of NRB. The DOM value after $48 \mathrm{~h}$ of incubation in the order from the highest to the lowest were the treatment of active $(57.8 \%)$, irradiated $(57.2 \%)$, autoclaved (56.1 \%), and without $\operatorname{NRB}(53.4 \%)$.

The bacteria and protozoa in the rumen liquid are indigenous biota that might be affected by the addition of the active or inactive NRB. The protozoa:bacteria ratioes from the treatment of either active or inactive NRB were lower than those without the addition of NRB. This shows that the NRB suppressed the growth of protozoa and may result in a decrease of methane production. The rumen protozoa and bacteria are well-known, and they have a mutualistic relationship in which the protozoa provide habitat for methanogenic bacteria. Methanogenic bacteria are associated with protozoa because of their role in the process of methanogenesis in the hydrogen transfer. $\mathrm{H}_{2}$ and $\mathrm{CO}_{2}$ from the feed fermentation in the rumen are converted into methane by methanogenic bacteria through hydrogen transfer. Consequently, the decline in protozoa community may cause a decrease of methane production [21].

From the $8^{\text {th }}$ to the $24^{\text {th }}$ hour of fermentation, the total gas increased in a high rate, then turned into steady stationary until the end of incubation (Fig. 1(a)). The pattern of gas production under all treatments were not significantly different. However, methane production was different among all treatments (Fig. 1(b)). After 24 and $48 \mathrm{~h}$ of incubation, the order of the methane production from the lowest to the highest was the treatment of active (2.0 and $8.0 \mathrm{ml} / 200 \mathrm{mg}$ ), irradiated (3.0 and 
$10.4 \mathrm{ml} / 200 \mathrm{mg})$, autoclaved (7.8 and $11.7 \mathrm{ml} / 200 \mathrm{mg})$, and without NRB (8.0 and $12.4 \mathrm{ml} / 200 \mathrm{mg})$.

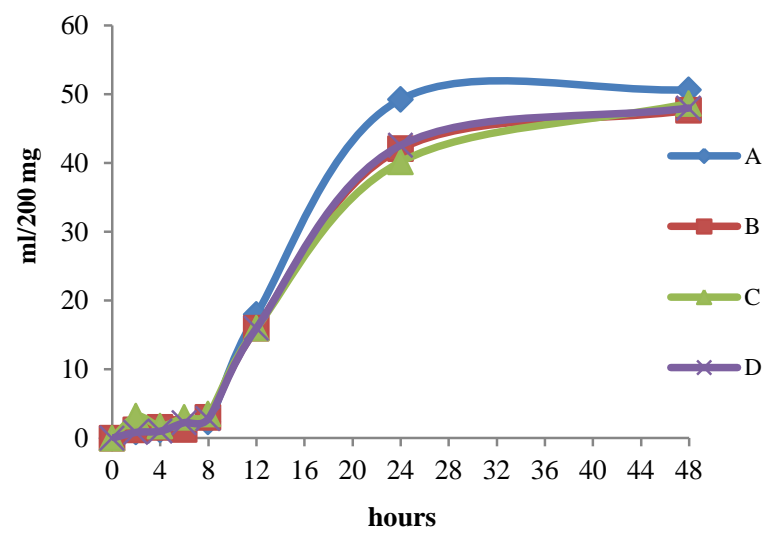

(a)

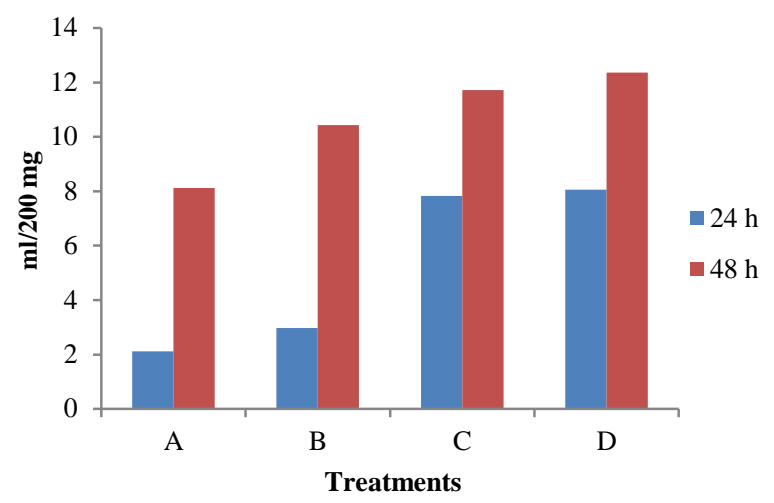

(b)

Fig. 1. Total gas (a) and methane production (b).

The percentages of differences in methane production between active and irradiated NRB were about $10.7 \%$ and $18.6 \%$ after 24 and $48 \mathrm{~h}$ incubation, respectively. The values were not significant for application as ruminant supplement. This proves that $\gamma$-irradiated NRB has the potential to be used as a reducing agent despite lower activity than active NRB because it can prevent the effects of acidosis in rumen liquid.

Increasing the population density of nitratereducing bacteria in the presence of nitrates was an effective means of inhibiting methanogenesis [6]. The addition of NRB such as Escherichia coli to the diet of sheep reduced the accumulation of nitrite in the rumen, though a further reduction in methane production was not detected [22]. Those responses differ from ours in that we observed a further decline in methanogenesis as a result of the addition of NRB. Besides, the inoculated isolate prevented the accumulation of nitrite; it is suggested that they possibly also protect against nitrite toxicity when nitrates are used. This process gives the benefit of lowering methane production in the rumen.
A model is proposed to illustrate the metabolisms of the active and inactive NRB (Fig. 2). When the active NRB are inoculated into rumen liquid, they will have the potency to grow and release the enzyme. Meanwhile, when the inactive NRB that had been either irradiated or autoclaved are inoculated into the rumen, they lose the ability to grow but still have the ability to produce the enzyme. The $\gamma$-irradiated NRB has a higher capacity to produce the enzyme than the autoclaved NRB. However, the damage by rradiation is not as severe as that by autoclaving. The hot steam and pressure from the autoclaving method bring about cell death, and the enzymes become denaturated. Consequently, the enzyme production and activity of the $\gamma$-irradiated NRB are higher; thus, they survive better in the rumen liquid than the autoclaved NRB. Therefore, when the $\gamma$-irradiated NRB are applied as a part of a feed supplement, they can suppress methane production in ruminants.

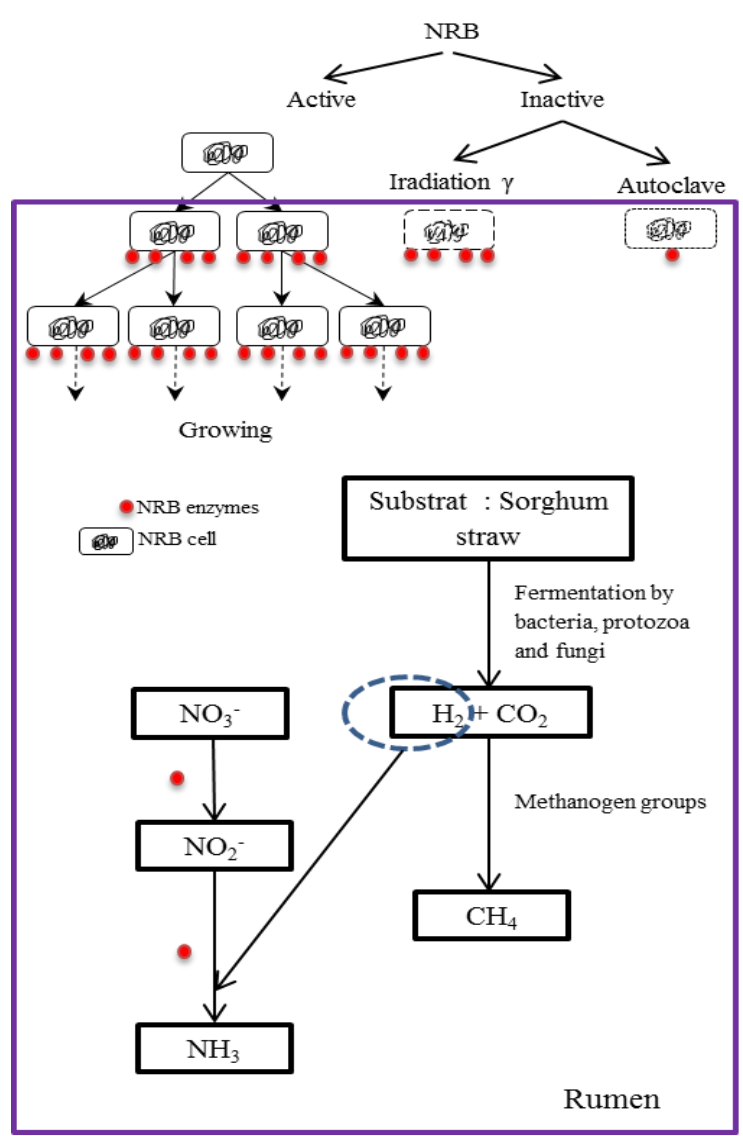

Fig. 2. The proposed model for active and inactive NRB metabolism in the rumen.

\section{CONCLUSION}

The $\gamma$-irradiated NRB has a potency for use as a supplement feed for buffaloes to decrease methane production without the risk of acidosis in the rumen liquid. 


\section{ACKNOWLEDGEMENT}

The authors gratefully acknowledge the Indonesian National Nuclear Energy Agency (BATAN) via Center for Isotopes and Radiation Application (CIRA) and Integrated Laboratory-State Islamic University Syarif Hidayatullah Jakarta, for supporting research funding and facilities to this research.

\section{REFERENCES}

1. G. Zervas and E. Tsiplakou, Atmospheric Env. 49 (2012) 13. doi:10.1016/j.atmosenv. 2011.11.039.

2. K.L. Lassey, Australian Journal of Experimental Agriculture 48 (2008) 114. doi:10.1071/EA07220.

3. Anonymous, Overview of Greenhouse Gases US Environmental Protection Agency, EPA (2016). https://www.epa.gov/ghgemissions/ overview-greenhouse-gases. Retrived in November (2016).

4. C. Martin, D.P. Morgavi and M. Doreau, Animal 4 (2010) 351. doi:10.1017/ S1751731109990620.

5. Anonymous, Tackling climate change through livestock - A global Assestment of Emission and Mitigation Opportunities. Food an Agriculture Organization, Rome (2013). www.fao.org/3/i3437e.pdf. Retrived in November (2016).

6. M. Iwamoto, N. Asanuma and T. Hino, Anim. Sci. J. 72 (2001) 117.

7. T. Yoshii, N. Asanuma and T. Hino, Anim. Sci. J. 76 (2005) 37. doi:10.1111/j.1740-0929.2005. 00235.x.

8. J. Takahashi and B.A.Young, Anim. Feed Sci. Tech. 35 (1991) 105. doi:10.1016/0377-8401 (91)90103-Y.
9. P.C. Sakthivel, D.N. Kamra, N. Agarwal et al., Asian-Australas. J. Anim. Sci. 25 (2012) 812. doi:10.5713/ajas.2011.11383.

10. J.C. Whittier, Livestock Series-Health, Fact Seet No. 1610, Colorado State University (2011). https://extension.colostate.edu/docs/ pubs/livestk/01610.pdf

11. D. Tetriana and I. Sugoro, J. Alara 2 (2007) 1.

12. N. Asanuma, M. Iwamoto, M. Kawato et al. Anim. Sci J. 73 (2002) 199. doi:10.1046/j.13443941.2002.00028.x.

13. P.J. Quinn, M.E. Carter, B.K. Markey et al., Clinical Veterinary Microbiology, MPG books Ltd, Bodmin, Cornwall, Great Britain (2001).

14. H.P.S. Makkar, FAO Animal Production and Health. Food and Agriculture Organization of the United Nations, Rome 160 (2004).

15. Anonymous, Laboratory Training Manual on The Use of Nuclear Technique in Animal Nutrition, IAEA (1985).

16. B. Pumphrey and C. Julien, Fermentation Basics (1996).

17. G. Fiorentini, I.P.C. Carvalho, J.D. Messana et al.; Asian-Australas. J. Anim. Sci. 28 (2015) 1583. doi:10.5713/ajas.15.0130.

18. Y. Kobayashi, Asian-Australas. J. Anim. Sci. 23 (2010) 410. doi:10.5713/ajas.2010.r.01

19. D.P. Morgavi, E. Forano, C. Martin et al., J. Animal 4 (2010) 1024.

20. M. Lin, D.M. Schaefer, W.S. Guo et al., AsianAustralas. J. Anim. Sci. 24 (2011) 471. doi:10.5713/ajas.2011.10288.

21. D.J. Cottle, J.V. Nolan and S.G. Wiedemann, Anim. Prod. Sci. 51 (2011) 491. doi:18360939/11/060491.

22. A. Machmüller, C.R. Soliva and M. Kreuzer, Br. J. Nutr. 90 (2003) 529. doi:10.1079/ BJN2003932. 